地 第 2 輯

第 41 巻（1988）129-131 頁

\section{簡便な地下水位・地下水温精密 連続観測テレメータシステム}

\author{
東海大学開発技術研究所 \\ 于259-12 平塚市北金目 1117
}

綱川秀夫・浅田 敏

(昭和 62 年 11 月 28 日受付;

昭和 63 年 1 月 22 日受理)

Convenient Telemetry System for Precise and

Continuous Measurement of Groundwater Level and Temperature

Hideo Tsunakawa and Toshi Asada

Institute of Research and Development, Tokai University

1117, Kitakaname, Hirastsuka 259-12

(Received November 28, 1987;

Accepted January 22, 1988)

地震の前兆現象として，数 $\mathrm{cm}$ から数 $+\mathrm{cm}$ の地下水 位が変化する場合があることはよく知られている [脇 田・他 (1980) 等]. また最近では, 地下水温もそのコサ イスミックな変化 $\left(10 \sim 100 \mathrm{~m}^{\circ} \mathrm{C}\right)$ が観測されている [ShIMAMURA et al. (1985)] ことから有力視されてきてい る.これらの観測が地震予知に寄与できるためには，少 なくとも地下水位 $1 \mathrm{~cm}$, 地下水温 $5 \mathrm{~m}^{\circ} \mathrm{C}$ 程度の相対的 精度が必要であろう. 我々は, この精度を十分満足し, かつ製作・設置・デー夕回収が簡単な装置を開発し実用 化したので報告する.

Fig. 1 に装置全体のブロック・ダイアグラムを示す. 地下水位センサーとしては, 差圧センサーPA500-501 G-06（コパル電子 KK）を使用した。このセンサーは半 導体よりなるセンサーチップをはり付けた膜の両側の差 圧を電圧として出力するものであり, 実際の観測では片 面を大気に通じさせているため水位変化のみによる圧力 変化を検出している. 電源は $12 \mathrm{VDC}$, 感度は $8 \mathrm{mV} / \mathrm{cm}$ であり, 0〜5 $\mathrm{m}$ の水位変化を $1 \sim 5 \mathrm{~V}$ の電圧変化とし て測定できる、実験室内で調べた結果, その直線性・温 度ドリフトとも問題なく，ノイズも水位換算で $0.1 \mathrm{~mm}$ 以下であった。このセンサーをしんちゅう製の容器（直 径 $40 \mathrm{~mm}$ 長さ $100 \mathrm{~mm}$ ）に入れて約 $2.5 \mathrm{~m}$ の深さに沈 め, 3 芯ヶーブルとステンレス線を通したビニール管で 地上に固定する。
地下水温を精密に測定する装置は, SHIMAMURA (1980)，島村 (1986) が水晶発振子を利用したものを製 作している. 我々は地下水温センサーとして, 水晶発振 子と比較してェレクトロニクス回路が単純であり入手し やすい半導体センサーLM35 を使用した。 ただしカ夕 ログ值では長期ドリフトが $\pm 80 \mathrm{~m}^{\circ} \mathrm{C} / 1000$ hours あ り、チェックを要する。これをしんちゅう製の容器（直 径 $25 \mathrm{~mm}$ 長さ $50 \mathrm{~mm}$ ）に入れて望みの深さに沈める. このセンサーは, 信号端子と電源のマイナス端子を 200 $\Omega$ の抵抗でっなぐことで, ッイスト線を使って地上の装 置での測定ができる．このッイスト線は中に鋼線が入っ ていて十分な破断強度を持ち，また電話線に使われるも のであって容易に手に入る. 感度は $10 \mathrm{mV} /{ }^{\circ} \mathrm{C}$ である.

データロガーとしては, 三洋電機 KK の DDR5310N （12 ビット A/D 変換， $\mathrm{AC} 100 \mathrm{~V} / \mathrm{DC} 12 \mathrm{~V}$ 両用）を使用 した. 綱川・横山 (1986) では, 16 ビット・インテリ ジェントデータロガーを使用したデー夕回収・テレメー タシステムを実用化しているが, 今の場合 12 ビットで 十分なのでより安価で維持が簡単なるのを使用した。地 下水位変化は, その信号電圧を DC オフセット（水銀電

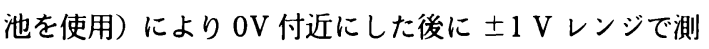
定する. したがって，分解能は約 $0.6 \mathrm{~mm}$ である. 地下 水温の信号電圧は DC オフセットにより $0 \mathrm{~V}$ 付近にし, 10 倍に増幅した後に $\pm 100 \mathrm{mV}$ レンジで測定する.こ の時の分解能は, $0.5 \mathrm{~m}^{\circ} \mathrm{C}$ である。サンプリング間隔は 5 分間とした。 DDR5310N は 32KB のラムカセットを 装備し，エンドレスでデータを書き込んでいくので, 常 に最近約 1 ケ月のデータを保持している.

地下水温の場合, 微小直流電圧を測定しなければなら ないため, 増幅器はチョッパスタビライズドアンプ (MA420) を使い, 電源はセンサーのも含めてすべてリ チゥム電池とした，また，周囲の温度変化によるアンプ

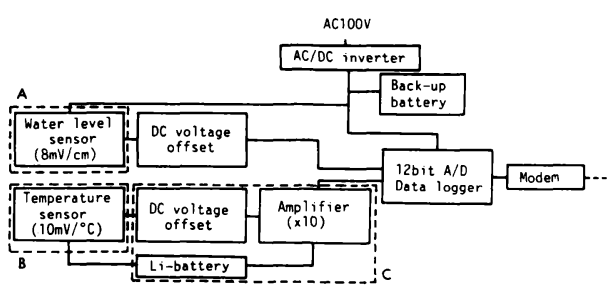

Fig. 1. Block diagram of the convenient system developed in this study for precise and continous measurement of groundwater level and temperature. At the Isshiki observation well (refer to Fig. 2), the device A, B and C are fixed at the depth of $2.5 \mathrm{~m}, 125 \mathrm{~m}$ and 23 $\mathrm{m}$, respectively. 

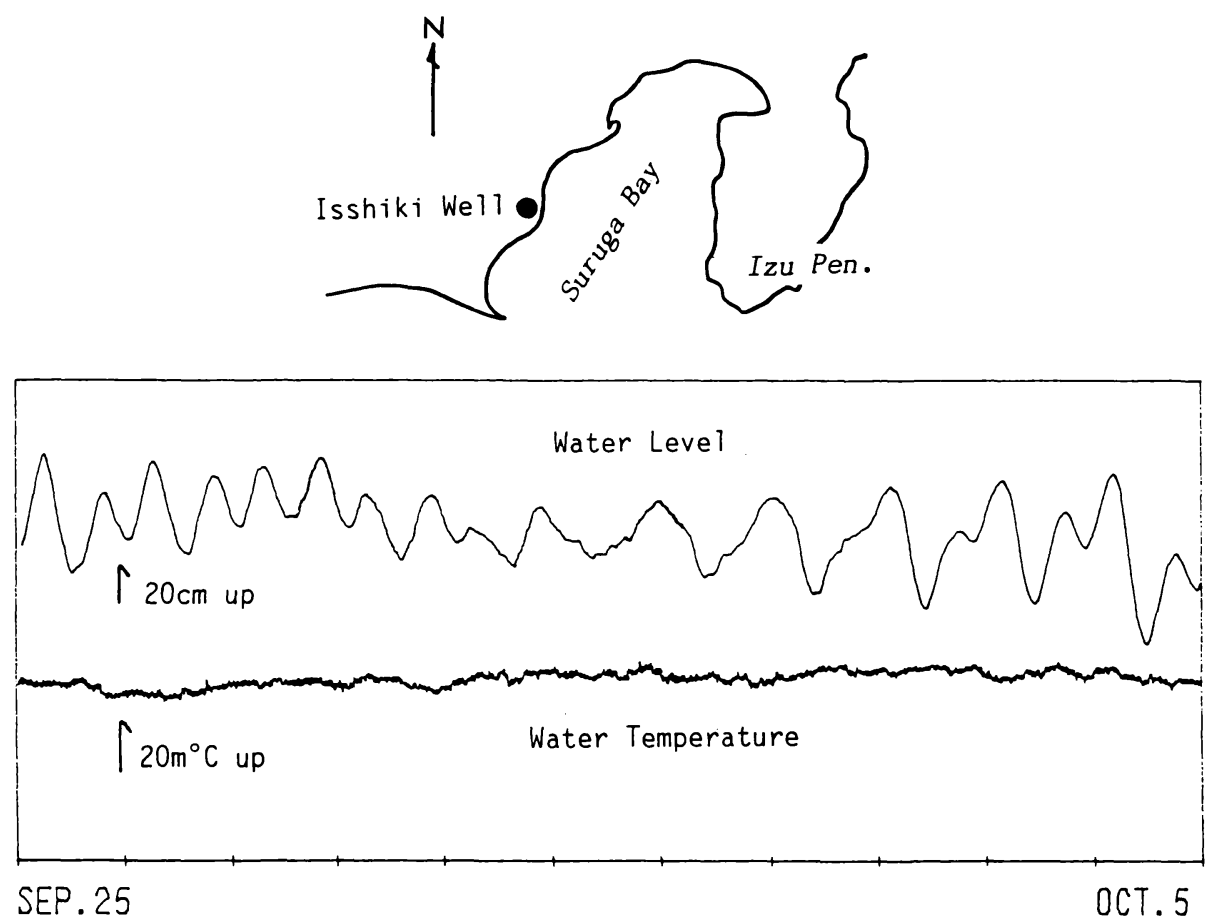

Fig. 2. Temporal changes of groundwater level and temperature at the Isshiki observation well in Shizuoka Prefecture from September 25th till October 5th in 1987. Groundwater temperature was measured at the depth of $125 \mathrm{~m}$.

の利得変動, 電源電圧変動などをなくすため, アンプ・ リチウム電池等を塩化ビニール管に入れ水深 $20 \sim 30 \mathrm{~m}$ のところに沈めてッイスト線で地上のデータロガーにつ なぐ．したがって, 少なくとも周囲温度の日変化は除去 できよう。この場合アンプ・リチウム電池等の発熱によ る影響は, $100 \mathrm{~m}$ 以上の深さの地下水温には及ばないで あろう。この地下水温計測システムは低消費電力になっ ており, データロガー（消費電力 $8 \mathrm{~W}$ ) を除いて単一型 リチゥム電池 6 個で $2 \sim 3$ 年間作動する.

テレメータは，モデムを通してNTT 公衆電話回線に より 1200 bps で行なう. ホストコンピュータとして PC9801F を使っており，観測地点を入力すれば電話呼 び出しからデータの回収, 回収途中での地下水位・水温 測定, データファイル作成まで, すべて自動化してある. このソフトゥェアの基本概念は, 綱川・横山 (1986) と ほぼ同じである．ただし，DDR5310N はインテリジェ ント機能を持たないので, 電話回線からのノイズを見る ためのチェックサムを送ることができない．この対策と して, 同じデー夕を最低限 2 回送らせてホスト側で受け 取ったデータが一致するかを調へ， 2 回連続して同じ值 になるまで送り続けることにした。

このようなシステムを使って, 実際に観測した例を示
す．場所は静岡県焼津市一㐌色観測井であり，1987 年 9 月から連続観測を始めた。この井戸は底まで $150 \mathrm{~m}$ あ り, ストレーナの位置は水深 109〜127 m のところであ る. 水面は地上約 $1 \mathrm{~m}$ まで上がっており被圧地下水であ る. 今回の観測では, ストレーナ最下部にあたる水深 $125 \mathrm{~m}$ のところで地下水温の観測を行なった。 この深度

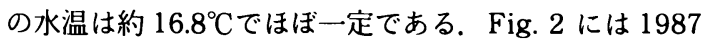
年 9 月 25 日から 10 月 5 日までの観測結果を示した。 地下水位には, 地球潮汐に関連した 24 時間・12 時間程 度の周期を持つ変化が数十 $\mathrm{cm}$ の振幅で顕著に現われて いる. またこの期間に観測された地下水温はほぼ一定で あり, 大きなドリフトは認められない,ただし, システ ムに由来すると思われる 1 時間以下の短周期ノイズが あり, その振幅は約 $2 \mathrm{~m}^{\circ} \mathrm{C}$ である. このノイズの原因の 可能性として $60 \mathrm{~Hz}$ 交流電源が考えられ, ッイスト線の 地上部分をより良いシールド線などにかえれば減少する かも知れない，以上の結果から，我々の開発した装置は 十分実用にたえるものと考える. 地下水位・水温の变化 そのあのについては別の機会に議論したい.

最後に，センサー等でご相談にのっていただいた北海 道大学島村英紀氏ならびに東京大学金沢敏夫氏に感謝い たします。 


\section{文献}

Shimamura, H., 1980, Precision quartz thermometers for borehole observations, J. Phys. Earth, 28, 243260.

島村英紀, 1986, 精密地下水温計, 北海道大学地球物理 学研究報告, 47, 1-15.

Shimamura, H., M. Ino, H. Hikawa and T. Iwasaki,
1985, Groundwater microtemperature in earthquake regions, Pure Appl. Geophys., 122, 933-946. 綱川秀夫・横山直樹, 1986, インテリジェントデータロ ガーを用いた簡便なデータ収集及びテレメータシステ 么, 地震 $2,39,472-474$.

脇田 宏・中村裕二・浅田 敏, 1980, 1980:1978 年伊 豆大島近海地震, および, 1978 年宮城県沖地震前の 地下水位の変化, 地震予知連会報, $23,60-62$. 